\title{
Ripening Behavior and Quality of 'Brazilian' Bananas following Hot Water Immersion to Disinfest Surface Insects
}

\author{
Marisa M. Wall ${ }^{1}$ \\ U.S. Department of Agriculture, Agricultural Research Service, U.S. Pacific \\ Basin Agricultural Research Center, P.O. Box 4459, Hilo, HI 96720-0459
}

Additional index words. postharvest, quarantine treatment, tropical fruit

\begin{abstract}
The fruit quality and ripening response of 'Brazilian' bananas (Musa sp., group $\mathrm{AAB}$ ) were determined following hot water immersion treatments for surface disinfestation. Summer-harvested fruit were exposed to 47,49 , or $51{ }^{\circ} \mathrm{C}$ water for 10,15 and 20 minutes and ripened at $20^{\circ} \mathrm{C}$. The summer experiment established the exposure time and temperature limits for fruit injury. Winter-harvested fruit were immersed in 48, 49, or $50{ }^{\circ} \mathrm{C}$ water for 5,10 and 15 minutes, stored for $12 \mathrm{~d}$ at $14{ }^{\circ} \mathrm{C}$, and ripened at $22{ }^{\circ} \mathrm{C}$. The hot water exposure time had a greater effect than the water temperature on banana fruit ripening. Nontreated bananas ripened after 13 to $15 \mathrm{~d}$, and ripening was delayed by 2 to $7 \mathrm{~d}$ when fruit were exposed for 15 or 20 minutes to hot water. Hot water treatments did not inhibit pulp softening, but peels tended to be firmer for bananas immersed in 49 to 51 ${ }^{\circ} \mathrm{C}$ water than control fruit. Heat-treated bananas were not different from control fruit in soluble solids content or titratable acidity, however the conversion of starch to sugars was reduced at higher temperatures and exposure times. Bananas exposed for 20 minutes to hot water had delayed respiratory peaks and ethylene production, especially at $51{ }^{\circ} \mathrm{C}$. Mild peel injury was observed on fruit exposed to higher temperatures $\left(49\right.$ to $\left.51{ }^{\circ} \mathrm{C}\right)$ for longer durations (15 or 20 minutes).
\end{abstract}

Fifteen to twenty percent of global banana production is traded internationally, and most bananas are of the Cavendish subgroup (Musa sp., AAA). Producing countries grow and consume a variety of domestic types that are genetically diverse (diploid, triploid, and tetraploid) (Turner, 1997). In Hawaii, the 'Brazilian' banana (Musa sp., group AAB), locally called the apple banana, is grown widely and marketed within the state (Simmonds, 1954). 'Brazilian' bananas had a farm gate value of $\$ 4.3$ million in 2001 (Hawaii Agricultural. Statistics Service, 2002). The fruit can be exported at the mature green stage under a nonhost quarantine status for Mediterranean [Ceratitis capitata Wiedemann)], melon [Bactrocera cucurbitae (Coquillet)], and oriental fruit flies [Bactrocera dorsalis (Hendel)] (Armstrong, 1983; 2001). However, quarantine inspections for the presence of "hitchhiker" surface insects can delay or impede the shipment of bananas, and lead to postharvest losses. The possible rejection of a shipment due to the presence of one or more surface insects poses a high financial risk for growers. Hot water immersion treatments are being investigated for disinfesting bananas from surface insects, especially the coconut scale [Aspidiotus destructor (Signoret)], a quarantine pest for bananas exported to Cali-

\footnotetext{
Received for publication 27 Oct. 2003. Accepted for publication 15 Jan. 2004. Mention of a trademark, warranty, proprietary product, or vendor does not constitute a guarantee by the U.S. Department of Agriculture and does not imply its approval to the exclusion of other products or vendors that may be suitable. The author thanks Sandra Silva, Suzanne Sanxter, Ryan Bosma, and Steve Brown for excellent assistance.

${ }^{1}$ E-mail mwall@pbarc.ars.usda.gov.
}

fornia from Hawaii. In preliminary studies, a $48.2{ }^{\circ} \mathrm{C}$ hot water treatment for $12.5 \mathrm{~min}$ killed coconut scales on the surface of bananas (unpublished data).

Hot water has been used more widely for postharvest disease control than for insect control (Couey, 1989). However, hot water immersion treatments have been developed to disinfest bananas, papayas (Carica papaya L.), longans (Dimocarpus longan Lour.), lychees (Litchee chinensis Sonn.), guavas (Psidium guajava L.), and mangoes (Mangifera indica L.) from tephritid fruit flies (Armstrong, 1982; Couey and Hayes, 1986; Follett and Sanxter, 2002; Follett and Sanxter, 2003; Gould and Sharp, 1992; Sharp and Spalding, 1984). Armstrong (1982) found that a $50{ }^{\circ} \mathrm{C}$ hot water immersion for $15 \mathrm{~min}$ was an effective quarantine treatment against Mediterranean, oriental and melon fruit flies without detriment to either banana appearance or shelf life if the fruit were at the unripe stage 1 or stage 2 (Del Monte, 1992). Riper fruit (stages 3 to 7) showed peel scalding. Reyes et al. (1998) found that exposing banana fruit to $50{ }^{\circ} \mathrm{C}$ hot water for 20 min reduced crown rot (Chalara paradoxa) incidence to $<3 \%$. Exposure to hot water at $55{ }^{\circ} \mathrm{C}$ for $10 \mathrm{~min}$ or longer caused severe skin scald and a failure to soften. Scald generally occured on fruit treated at $50^{\circ} \mathrm{C}$ when exposure time was $30 \mathrm{~min}$ or longer, and there were seasonal differences in the severity of fruit injury. Except for scald, no physiological and quality responses to hot water immersion were determined in these studies.

The objectives of this study were to determine the quality and fruit ripening patterns of 'Brazilian' bananas following hot waterimmersion treatments for surface disinfestation.
Experiment 1. Bananas (Musa sp., 'Brazilian', "apple", AAB group) were harvested on 1 May, 10 July, and 21 Aug. 2002 from an orchard near Keaau, Hawaii. Only mature green (stage 1) fruit were selected. Two bunches were selected at each harvest date, for a total of six bunches. A bunch represented a block for statistical analyses. Three hands were removed from the middle of each bunch and labeled. The hands were transported immediately to the laboratory and cut into clusters with four fruit per cluster.

The clusters from a bunch were randomly assigned to 10 treatments (described below). One finger was removed from each cluster and placed into 2-L glass jars with lids fitted with septa. After $2 \mathrm{~h}$, gas samples were removed for initial respiration and ethylene measurements. Carbon dioxide evolution was determined with an infrared gas analyzer (model 6600; Illinois Instruments, Johnsburg, Ill.), and ethylene was measured using a gas chromatograph (model 5830A; Hewlett Packard) fitted with an alumina column and a flame ionization detector.

Degree of ripenesss was assessed on peel color using an industry scale of 1 (dark green), 2 (green, trace of yellow), 3 (half green-half yellow), 4 (three quarters yellow with green), 5 (yellow with green tip), 6 (full yellow), and 7 (yellow with black spots) (Del Monte, 1992). In addition, surface color measurements were taken at three positions per fruit for all fingers in a cluster with a chromameter (model CR-300; Minolta Corp., Ramsey, N.J.) and recorded as lightness $\left(\mathrm{L}^{*}\right)$, chroma $\left(\mathrm{C}^{*}\right)$, and hue angle $\left(\mathrm{H}^{\circ}\right)$ under standard illuminant $\mathrm{C}$.

Hot waterimmersion treatments were applied to the fruit clusters on the morning after harvest. Fruit clusters were placed in plastic mesh bins $(16.5 \times 26 \times 6.3 \mathrm{~cm})$ with lids. The bins had openings over at least $60 \%$ of the surface area for watercirculation through the bins. The water bath was heated withimmersion circulators (model 73; Polyscience, Niles, Ill.). The water temperature was monitored continuously with thermisters and a datalogger (Omnidata International, Inc., Logan, Utah). There were 10 treatments: 9 hot water treatments ( 3 temperatures $\times 3$ times) plus a control. The treatments were selected to establish the upper limits that caused fruit injury, while remaining within a range of temperatures that may kill surface insects. Fruit were immersed in 47,49 , or $51^{\circ} \mathrm{C}$ hot water for 10,15 , and 20 min. All fruit were immediately cooled in $24^{\circ} \mathrm{C}$ water for $20 \mathrm{~min}$ following hot water treatment. Control fruit were not immersed in hot water. After treatment, fruit were air dried and placed at $20{ }^{\circ} \mathrm{C}$ to ripen.

Respiration, ethylene, and surface color measurements were repeated on the fingers 1 $\mathrm{d}$ following hot water treatment and every 2 $\mathrm{d}$, thereafter, until the fruit had reached stage 6 of the ripeness scale. At that time, final nondestructive measurements were made, and destructive measurements for firmness, percent soluble solids, starch content, and sugar concentrations were conducted. Firmness was measured using a force gauge (Ametek, Largo, Fla.) having an 8-mm-diameter probe, 
Table 1. Composition of summer-harvested 'Brazilian' bananas following hot water immersion treatments and ripening at $20{ }^{\circ} \mathrm{C}$.

\begin{tabular}{|c|c|c|c|c|c|c|}
\hline \multirow[b]{2}{*}{ Treatment } & \multirow{2}{*}{$\begin{array}{l}\text { Days to } \\
\text { ripening }\end{array}$} & \multicolumn{5}{|c|}{ Concn (mg. $\mathrm{g}^{-1}$ fresh wt) } \\
\hline & & Starch $^{y}$ & Sucrose & Glucose & Fructose & Total \\
\hline Control & $13.1 \mathrm{a}^{\mathrm{x}}$ & $51.3 \mathrm{a}$ & $99.4 \mathrm{a}$ & $25.8 \mathrm{ab}$ & $18.7 \mathrm{a}$ & $143.9 \mathrm{a}$ \\
\hline $47^{\circ} \mathrm{C}, 10 \mathrm{~min}$ & $14.4 \mathrm{abc}$ & $72.6 \mathrm{abc}$ & $96.3 \mathrm{a}$ & $21.7 \mathrm{abc}$ & $15.7 \mathrm{abc}$ & $133.7 \mathrm{a}$ \\
\hline $15 \mathrm{~min}$ & $14.3 \mathrm{abc}$ & $53.7 \mathrm{ab}$ & $97.2 \mathrm{a}$ & $26.8 \mathrm{a}$ & $19.4 \mathrm{a}$ & $143.4 \mathrm{a}$ \\
\hline $20 \mathrm{~min}$ & $16.1 \mathrm{bcd}$ & $80.0 \mathrm{bc}$ & $89.8 \mathrm{a}$ & $21.6 \mathrm{abc}$ & $15.2 \mathrm{abc}$ & $126.6 \mathrm{a}$ \\
\hline $49^{\circ} \mathrm{C}, 10 \mathrm{~min}$ & $14.2 \mathrm{ab}$ & $75.6 \mathrm{abc}$ & $86.2 \mathrm{a}$ & $22.3 \mathrm{abc}$ & $16.1 \mathrm{abc}$ & $124.6 \mathrm{a}$ \\
\hline $15 \mathrm{~min}$ & $16.5 \mathrm{~cd}$ & $58.8 \mathrm{ab}$ & $85.0 \mathrm{a}$ & $23.7 \mathrm{ab}$ & $17.3 \mathrm{ab}$ & $126.0 \mathrm{a}$ \\
\hline $20 \mathrm{~min}$ & $17.2 \mathrm{~d}$ & $91.1 \mathrm{c}$ & $89.1 \mathrm{a}$ & $19.0 \mathrm{bc}$ & $13.9 \mathrm{bc}$ & $122.0 \mathrm{a}$ \\
\hline $51^{\circ} \mathrm{C}, 10 \mathrm{~min}$ & $14.6 \mathrm{abc}$ & $75.3 \mathrm{abc}$ & $90.4 \mathrm{a}$ & $22.1 \mathrm{abc}$ & $15.8 \mathrm{abc}$ & $128.3 \mathrm{a}$ \\
\hline $15 \min$ & $16.9 \mathrm{~d}$ & $88.9 \mathrm{c}$ & $85.2 \mathrm{a}$ & $23.1 \mathrm{abc}$ & $16.7 \mathrm{ab}$ & $125.0 \mathrm{a}$ \\
\hline $20 \mathrm{~min}$ & $19.9 \mathrm{e}$ & $97.2 \mathrm{c}$ & $82.1 \mathrm{a}$ & $16.6 \mathrm{c}$ & $12.1 \mathrm{c}$ & $110.8 \mathrm{a}$ \\
\hline
\end{tabular}

${ }^{\mathrm{z}}$ Average number of days to reach stage six maturity (full yellow). Values are means for 24 observations.

${ }^{y}$ Starch and sugar values are means of six replications, with a composite sample of four bananas per replication.

${ }^{x}$ Means within columns followed by the same letter are not significantly different $(P>0.05)$ according to the Waller Duncan k ratio $t$ test.

and mounted on a motorized test stand. The peak force $(\mathrm{kg})$ was measured at a penetration depth of $7 \mathrm{~mm}$, and the data were converted to Newtons (N). A 10-g sample of pulp was homogenized with $10 \mathrm{~g}$ water for $1 \mathrm{~min}$, and the soluble solids of the liquid was measured with a refractometer (Atago, Kirkland, Wash.).

For starch and sugar determinations, pulp $(10 \mathrm{~g})$ from four fruits was combined in a test tube and homogenized in $80 \%$ ethanol for 1 min at high speed. The slurry was immediately boiled for $15 \mathrm{~min}$, cooled, and filtered through Whatman \#4 paper. The filter cake was rinsed with additional ethanol, and dried for $48 \mathrm{~h}$ at $70{ }^{\circ} \mathrm{C}$ to obtain the alcohol insoluble solids (AIS) for starch analysis. The sugar extract was brought to a final volume of $100 \mathrm{~mL}$ with $80 \%$ ethanol. A 5-mL aliquot was filtered through a $0.22 \mu \mathrm{m}$ membrane filter into vials for high pressure liquid chromatography (HPLC).

HPLC was used to separate and quantify glucose, fructose, and sucrose in the banana samples. Carbohydrates were analyzed by injecting $20 \mu \mathrm{L}$ of sample into an Agilent 1100 series liquid chromatograph (Agilent Technologies, Wilmington, Del.) with premixed HPLC-grade water $(25 \%)$ and acetonitrile (75\%) as the mobile phase, and an aminopropylsilane column as the stationary phase (Agilent ZORBAX carbohydrate analysis column, $4.6 \mathrm{~mm}$ ID $\times 150 \mathrm{~mm}, 5 \mu \mathrm{m})$, followed by an Agilent refractive index detector. A flow rate of $1.4 \mathrm{~mL} \cdot \mathrm{min}^{-1}$ was used, and the column and detector temperatures were set at $30{ }^{\circ} \mathrm{C}$. The mobile phase was vacuum filtered through a $0.45-\mu \mathrm{m}$ membrane filter before use.

Sucrose, glucose, and fructose standards were prepared at five concentrations ranging from 250 to $2000 \mu \mathrm{g} \cdot \mathrm{mL}^{-1}$ to calibrate the HPLC. Carbohydrate peaks of the samples were identified according to HPLC retention times in comparison with authentic standards. For recovery tests, samples were spiked with standard solutions before extraction. The detection limit for each sugar was $1 \mu \mathrm{g}$, and the recovery was $95 \%$.

Starch was determined by combining 30 $\mathrm{mg}$ of AIS with $10 \mathrm{~mL}$ distilled water, and heating at $100{ }^{\circ} \mathrm{C}$ in a water bath for $90 \mathrm{~min}$ (Hagenimana et al., 1994). A soluble starch standard was included also. After cooling, $5 \mathrm{~mL}$ of 0.01 M sodium acetate ( $\mathrm{pH} 4.5$ ) containing
10 units/mL of amyloglucosidase was added to each sample and the standard. The test tubes were incubated at $55^{\circ} \mathrm{C}$ for $30 \mathrm{~min}$. Following enzymatic hydrolysis, the total reducing sugars were measured using the method of Blakeney and Mutton (1980).

Experiment 2. Fruit for Expt. 2 were harvested in the winter (7 Jan. and 11 Feb. 2003) from an orchard in Pepeekeo, Hawaii. Mature green (stage 1) fruit were destined for the mainland market and were harvested 1 week earlier than fruit for local market. Fruit were sampled and prepared for hot water immersion treatments in the same manner as for Expt. 1. However, based on the results of Expt. 1 and preliminary studies with coconut scales, the ranges of temperatures and exposure times were narrowed. The hot water immersion treatments were 48,49 , or $50^{\circ} \mathrm{C}$ for 5,10 , and $15 \mathrm{~min}$. Fruit were immediately cooled in $24^{\circ} \mathrm{C}$ water for $15 \mathrm{~min}$. Control fruit were immersed in 24 ${ }^{\circ} \mathrm{C}$ water for $15 \mathrm{~min}$.

Following treatment, the fruit were stored for $12 \mathrm{~d}$ at $14{ }^{\circ} \mathrm{C}$ and $89 \%$ relative humidity $(\mathrm{RH})$ to simulate shipping and distribution on the mainland. Fruit were stored in plastic bags with perforations, designed for bananas, and placed into cardboard boxes. After storage, the fruit were ripened at $22{ }^{\circ} \mathrm{C}$.

All quality evaluations and analytical methods were the same as in Expt. 1, however destructive analyses were performed when the fruit reached stage 7 . In addition, a peel

Table 2. Firmness and color of summer-harvested 'Brazilian' bananas following hot water immersion treatments and ripening at $20^{\circ} \mathrm{C}$.

\begin{tabular}{|c|c|c|c|c|c|}
\hline \multirow[b]{2}{*}{ Treatment } & \multirow{2}{*}{$\begin{array}{l}\text { Stage of } \\
\text { ripeness }\end{array}$} & \multicolumn{2}{|c|}{ Firmness $(\mathrm{N})^{\mathrm{y}}$} & \multicolumn{2}{|c|}{ Peel color $^{\mathrm{x}}$} \\
\hline & & Peel & Pulp & $\mathrm{L}^{*}$ & Hue $\left(^{\circ}\right)$ \\
\hline Control & $6.0 \mathrm{a}^{\mathrm{w}}$ & $22.19 \mathrm{a}$ & $4.97 \mathrm{a}$ & $70.1 \mathrm{ab}$ & $89.6 \mathrm{a}$ \\
\hline $47^{\circ} \mathrm{C}, 10 \mathrm{~min}$. & $6.1 \mathrm{a}$ & $28.06 \mathrm{ab}$ & $5.28 \mathrm{a}$ & $70.1 \mathrm{ab}$ & $89.4 \mathrm{ab}$ \\
\hline $15 \mathrm{~min}$ & $6.2 \mathrm{ab}$ & $25.77 \mathrm{ab}$ & $4.81 \mathrm{a}$ & $70.5 \mathrm{a}$ & $89.6 \mathrm{a}$ \\
\hline $20 \mathrm{~min}$. & $6.4 \mathrm{~b}$ & $28.15 \mathrm{ab}$ & $5.24 \mathrm{a}$ & $69.4 \mathrm{abc}$ & $89.0 \mathrm{abc}$ \\
\hline $49^{\circ} \mathrm{C}, 10 \mathrm{~min}$. & $6.2 \mathrm{ab}$ & $26.57 \mathrm{ab}$ & $5.28 \mathrm{a}$ & $69.4 \mathrm{abc}$ & $89.6 \mathrm{a}$ \\
\hline $15 \mathrm{~min}$. & $6.4 \mathrm{~b}$ & $28.50 \mathrm{ab}$ & $4.96 \mathrm{a}$ & $69.0 \mathrm{bc}$ & $88.6 \mathrm{bcd}$ \\
\hline $20 \mathrm{~min}$. & $6.2 \mathrm{ab}$ & $37.31 \mathrm{~cd}$ & $6.61 \mathrm{a}$ & $68.2 \mathrm{c}$ & $88.0 \mathrm{~cd}$ \\
\hline $51^{\circ} \mathrm{C}, 10 \mathrm{~min}$. & $6.0 \mathrm{a}$ & $31.09 \mathrm{bc}$ & $5.24 \mathrm{a}$ & $70.0 \mathrm{ab}$ & $89.4 \mathrm{ab}$ \\
\hline $15 \mathrm{~min}$. & $6.3 \mathrm{~b}$ & 30.99 bc & $6.54 \mathrm{a}$ & $68.2 \mathrm{c}$ & $87.8 \mathrm{~d}$ \\
\hline $20 \mathrm{~min}$. & $6.7 \mathrm{c}$ & $43.70 \mathrm{~d}$ & $8.25 \mathrm{a}$ & $63.9 \mathrm{~d}$ & $85.1 \mathrm{e}$ \\
\hline
\end{tabular}

${ }^{\mathrm{z}}$ Mean stage of ripeness when destructive analyses were performed Stage of ripenesss was assessed on peel color using a scale of $1=$ dark green, $2=$ green with a trace of yellow, $3=$ more green than yellow, $4=$ more yellow than green, $5=$ green tip, $6=$ fully yellow, and $7=$ yellow with black spots. Values are means of 24 observations.

Values are means of 24 observations.

${ }^{x}$ Lightness $\left(\mathrm{L}^{*}\right)$ is on a scale of 0 to 100 . A hue angle of $90^{\circ}=$ yellow. Values are means of 24 observations.

${ }^{\mathrm{w}}$ Means within columns followed by the same letter are not significantly different $(P>0.05)$. 

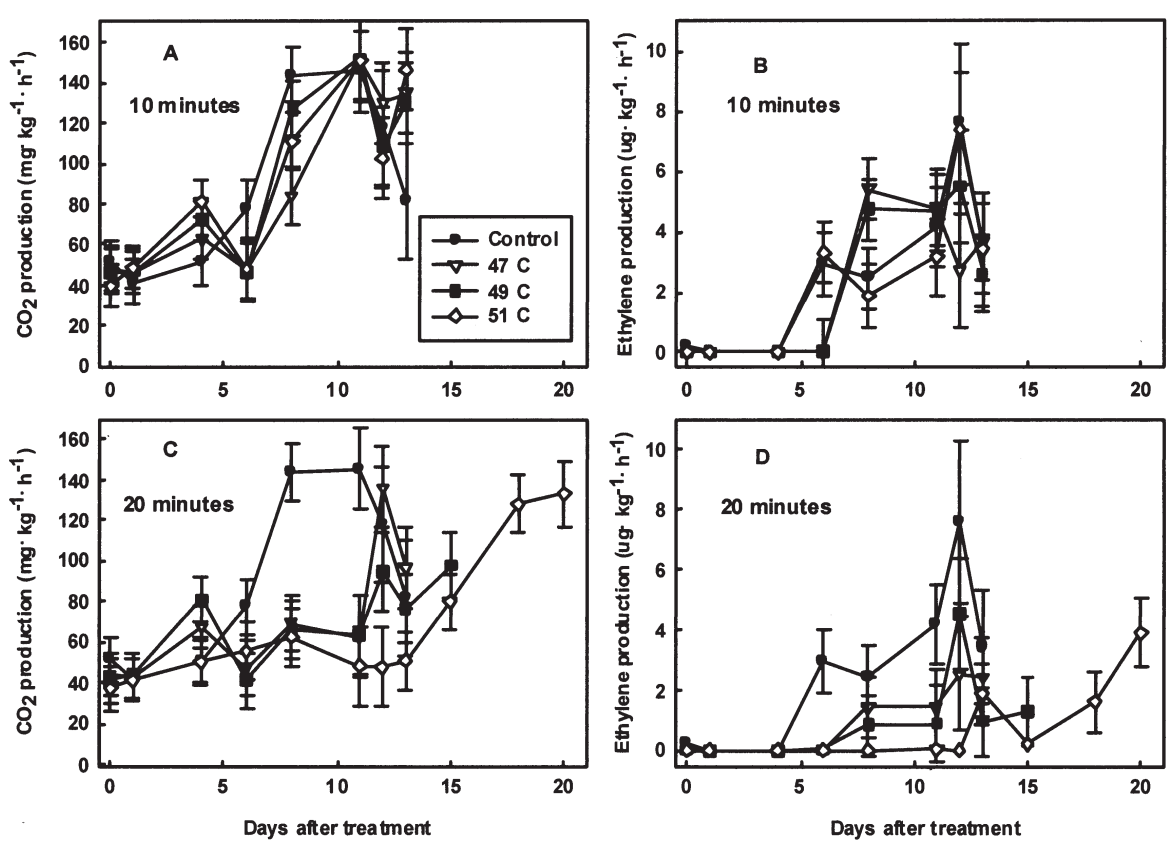

Fig. 1. Carbon dioxide (A and $\mathbf{C}$ ) and ethylene (B and $\mathbf{D})$ production of summer-harvested 'Brazilian' bananas immersed in 47,49 , and $51^{\circ} \mathrm{C}$ hot water for $10(\mathbf{A}$ and $\mathbf{B})$ or $20(\mathbf{C}$ and $\mathbf{D}) \mathrm{min}$.

at a similar rate as control fruit (Table 1). Ripening was delayed by 3 to $7 \mathrm{~d}$ when fruit were exposed for $20 \mathrm{~min}$ to 47,49 , or $51{ }^{\circ} \mathrm{C}$ hot water treatments. Ripening was incomplete for some individual fingers treated for $20 \mathrm{~min}$ at $51{ }^{\circ} \mathrm{C}$. Nontreated 'Brazilian' bananas ripened after $13 \mathrm{~d}$ (Table 1). This is similar to 'Dwarf Brazilian' bananas that ripened in $14 \mathrm{~d}$ at 20 ${ }^{\circ} \mathrm{C}$ (Paull, 1996).

Treatments differed in their effects on banana peel firmness $(P=0.0001)$, but not pulp firmness $(P=0.22)$ (Table 2). Fruit exposed to $49{ }^{\circ} \mathrm{C}$ water for $20 \mathrm{~min}$ or $51{ }^{\circ} \mathrm{C}$ for 10 to 20 min had firmer peels than control fruit (Table 2). Also, peel scalding and darkening were observed only on fruit treated with $51^{\circ} \mathrm{C}$ water for 15 or $20 \mathrm{~min}$ (data not shown).

Hot water treatments did not affect the total sugar $(P=0.29)$ or sucrose concentrations $(\mathrm{P}=$ 0.55 ) of ripening bananas (Table 1 ). However, the starch concentrations remained higher than control fruit for bananas treated for $15 \mathrm{~min}$ at $51^{\circ} \mathrm{C}$, and for $20 \mathrm{~min}$ at 47,49 , or $51^{\circ} \mathrm{C}$ hot water. Glucose and fructose concentrations were reduced in bananas immersed in 49 or $51{ }^{\circ} \mathrm{C}$ hot water for $20 \mathrm{~min}$ compared with control fruit.
The respiration rates of bananas exposed for 10 min to 47,49 , or $51^{\circ} \mathrm{C}$ water were similar to the rates for nontreated bananas (Figure 1a). Fruit exposed for $20 \mathrm{~min}$ to hot water had delayed respiratory peaks and ripening, especially at $51{ }^{\circ} \mathrm{C}$ (Fig. 1c). Fruit in treatments exhibiting decreased $\mathrm{CO}_{2}$ production also tended to have the highest starch and lowest sugar concentrations. The conversion of starch to sugars during banana ripening involves several enzymes and pathways, and requires energy (Seymour, 1993). Exposure to hot water $\left(49\right.$ and $51^{\circ} \mathrm{C}$ ) for 20 min may have inhibited starch hydrolytic enzymes, therefore less carbon was available to enter the glycolytic and gluconeogenic pathways. Also, ripening is dependent on the maintenance of glycolysis to provide energy for sugar synthesis (gluconeogenesis) (Beaudry et al., 1989).

Ethylene production of control fruit peaked after $12 \mathrm{~d}$ of ripening (Fig. 1b). Paull (1996) reported that ethylene peaked $10 \mathrm{~d}$ after harvest for 'Dwarf Brazilian' bananas ripened at $22.5^{\circ} \mathrm{C}$. Ethylene production was reduced and delayed for bananas immersed in hot water for $20 \mathrm{~min}$, especially at $51{ }^{\circ} \mathrm{C}$ (Fig. 1d). High temperature exposure can inhibit ethylene production in fruits through inactivation of 1aminocyclopropane-1-carboxylic acid (ACC) synthase and ACC oxidase (Chan, 1986; Ketsa et al., 1999).

Experiment 2. Fruit ripening was delayed by 2 to $6 \mathrm{~d}$ in bananas immersed for $15 \mathrm{~min}$ in 48,49 , or $50{ }^{\circ} \mathrm{C}$ water (Table 3). Control fruit placed at $22^{\circ} \mathrm{C}$ ripened $15 \mathrm{~d}$ after removal from $14{ }^{\circ} \mathrm{C}$ storage, for a total postharvest life of $27 \mathrm{~d}$. 'Dwarf Brazilian' bananas stored 14 d at $15^{\circ} \mathrm{C}$, and ripened at $20^{\circ} \mathrm{C}$, had a similar postharvest life of $28 \mathrm{~d}$ (Paull, 1996).

Heat-treated bananas were not different from control fruit in soluble solids content $(P=$ $0.78)$, titratable acidity $(P=0.64)$, and glucose, fructose and sucrose concentrations $(P=0.19$, $0.21,0.24$, respectively). However, differences among treatments were detected for starch $(P$ $=0.03)$ and total sugar concentrations $(P=$ 0.02 ), indicating that the conversion of starch to sugars was reduced at higher temperatures and exposure times.

The fruit were evaluated at stage 7 ripeness in Expt. 2, because 'Brazilian' bananas are commonly consumed at this stage. Therefore, starch concentrations were lower and sugar concentrations higher in Expt. 2 when compared with Expt. 1. In both experiments, sugar concentrations were high when compared with values reported for 'Cavendish' bananas (Musa sp.,AAA group). The total sugar concentration of ripe 'Cavendish' bananas was $113.8 \mathrm{mg} \cdot \mathrm{g}^{-1}$ (Li et al., 2002), whereas the sugar concentrations of 'Brazilian' bananas were 143.9 and $177.6 \mathrm{mg} \cdot \mathrm{g}^{-1}$ for summer and winter harvested fruit, respectively (Tables 1 and 3).

In Expt. 2, the respiration rates of control fruit were similar to fruit in Expt. 1, reaching a peak at $138 \mathrm{mg} \cdot \mathrm{kg}^{-1} \cdot \mathrm{h}^{-1}$ (Fig. 2a). Carbon dioxide production remained elevated after the climacteric, as described by Beaudry et al. (1989). The respiratory response of fruit exposed for $10 \mathrm{~min}$ to hot water also was similar to Expt. 1 (Figs. 1a and 2a). However, there was some delay in the respiratory rise in fruit immersed for $15 \mathrm{~min}$, especially at 50 ${ }^{\circ} \mathrm{C}$ (Fig. 2c). This was not as pronounced as the 20 min exposure to $51{ }^{\circ} \mathrm{C}$ water in Expt. 1 (Fig. 1c).

Ethylene production reached peak levels (9.7 to $12.9 \mu \mathrm{g} \cdot \mathrm{kg}^{-1} \cdot \mathrm{h}^{-1}$ ) $18 \mathrm{~d}$ after storage for fruit exposed to hot water for 0 or $10 \mathrm{~min}$ (Fig. $2 b$ ). Ethylene production was suppressed for bananas exposed to $50{ }^{\circ} \mathrm{C}$ water for $15 \mathrm{~min}$

Table 3. Composition of winter-harvested 'Brazilian' bananas following hot water immersion treatments, storage at $14{ }^{\circ} \mathrm{C}$ for $12 \mathrm{~d}$, and ripening at $22{ }^{\circ} \mathrm{C}$.

\begin{tabular}{|c|c|c|c|c|c|c|c|c|}
\hline \multirow[b]{2}{*}{ Treatment } & \multirow{2}{*}{$\begin{array}{l}\text { Days to } \\
\text { ripening }\end{array}$} & \multirow{2}{*}{$\begin{array}{c}\text { Soluble } \\
\text { solids }(\%)^{y}\end{array}$} & \multirow{2}{*}{$\begin{array}{c}\text { Titratable } \\
\text { acidity }(\%)\end{array}$} & \multicolumn{5}{|c|}{ Concn $\left(\mathrm{mg} \cdot \mathrm{g}^{-1}\right.$ fresh wt) } \\
\hline & & & & Starch & Sucrose & Glucose & Fructose & Total \\
\hline$\overline{\text { Control }}$ & $15.3 \mathrm{a}^{\mathrm{x}}$ & $25.7 \mathrm{a}$ & $0.65 \mathrm{a}$ & $4.6 \mathrm{a}$ & $114.2 \mathrm{a}$ & $31.6 \mathrm{a}$ & $31.8 \mathrm{a}$ & $177.6 \mathrm{a}$ \\
\hline $48^{\circ} \mathrm{C}, 5 \mathrm{~min}$ & $17.5 \mathrm{~d}$ & $25.4 \mathrm{a}$ & $0.60 \mathrm{a}$ & $7.6 \mathrm{ab}$ & $103.5 \mathrm{a}$ & $31.6 \mathrm{a}$ & $31.7 \mathrm{a}$ & $166.8 \mathrm{ab}$ \\
\hline $10 \mathrm{~min}$ & $16.0 \mathrm{abc}$ & $25.3 \mathrm{a}$ & $0.65 \mathrm{a}$ & $13.7 \mathrm{bc}$ & $101.3 \mathrm{a}$ & $26.9 \mathrm{a}$ & $26.9 \mathrm{a}$ & $155.0 \mathrm{abc}$ \\
\hline $15 \mathrm{~min}$ & $17.0 \mathrm{bcd}$ & $24.9 \mathrm{a}$ & $0.66 \mathrm{a}$ & $10.9 \mathrm{abc}$ & $107.7 \mathrm{a}$ & $25.7 \mathrm{a}$ & $25.6 \mathrm{a}$ & $159.0 \mathrm{abc}$ \\
\hline $49^{\circ} \mathrm{C}, 5 \mathrm{~min}$ & $17.3 \mathrm{~cd}$ & $25.6 \mathrm{a}$ & $0.60 \mathrm{a}$ & $9.6 \mathrm{abc}$ & $95.8 \mathrm{a}$ & $29.5 \mathrm{a}$ & $29.4 \mathrm{a}$ & $154.7 \mathrm{abc}$ \\
\hline $10 \mathrm{~min}$ & $17.0 \mathrm{bcd}$ & $24.8 \mathrm{a}$ & $0.65 \mathrm{a}$ & $14.3 \mathrm{bc}$ & $87.5 \mathrm{a}$ & $22.5 \mathrm{a}$ & $22.5 \mathrm{a}$ & $132.4 \mathrm{c}$ \\
\hline $15 \min$ & $17.5 \mathrm{~d}$ & $24.8 \mathrm{a}$ & $0.68 \mathrm{a}$ & $15.5 \mathrm{c}$ & $92.1 \mathrm{a}$ & $21.5 \mathrm{a}$ & $21.4 \mathrm{a}$ & $135.0 \mathrm{c}$ \\
\hline $50^{\circ} \mathrm{C}, 5 \mathrm{~min}$ & $15.8 \mathrm{ab}$ & $24.6 \mathrm{a}$ & $0.68 \mathrm{a}$ & $14.0 \mathrm{bc}$ & $86.7 \mathrm{a}$ & $23.9 \mathrm{a}$ & $23.9 \mathrm{a}$ & $134.5 \mathrm{c}$ \\
\hline $10 \mathrm{~min}$ & $15.8 \mathrm{ab}$ & $24.6 \mathrm{a}$ & $0.72 \mathrm{a}$ & $13.2 \mathrm{bc}$ & $97.3 \mathrm{a}$ & $22.4 \mathrm{a}$ & $22.4 \mathrm{a}$ & $142.1 \mathrm{bc}$ \\
\hline $15 \mathrm{~min}$ & $21.0 \mathrm{e}$ & $25.0 \mathrm{a}$ & $0.64 \mathrm{a}$ & $13.7 \mathrm{bc}$ & $99.0 \mathrm{a}$ & $28.0 \mathrm{a}$ & $28.1 \mathrm{a}$ & $155.1 \mathrm{abc}$ \\
\hline
\end{tabular}

${ }^{2}$ Average number of days to reach stage 6 to 7 maturity following $12 \mathrm{~d}$ storage at $14{ }^{\circ} \mathrm{C}$. Values are means for 12 observations.

${ }^{y}$ Soluble solids, titratable acidity, starch, and sugar values are means of four replications, with a composite sample of three bananas per replication.

${ }^{x}$ Means within columns followed by the same letter are not significantly different $(P>0.05)$ according to the Waller Duncan $\mathrm{k}$ ratio $t$ test. 

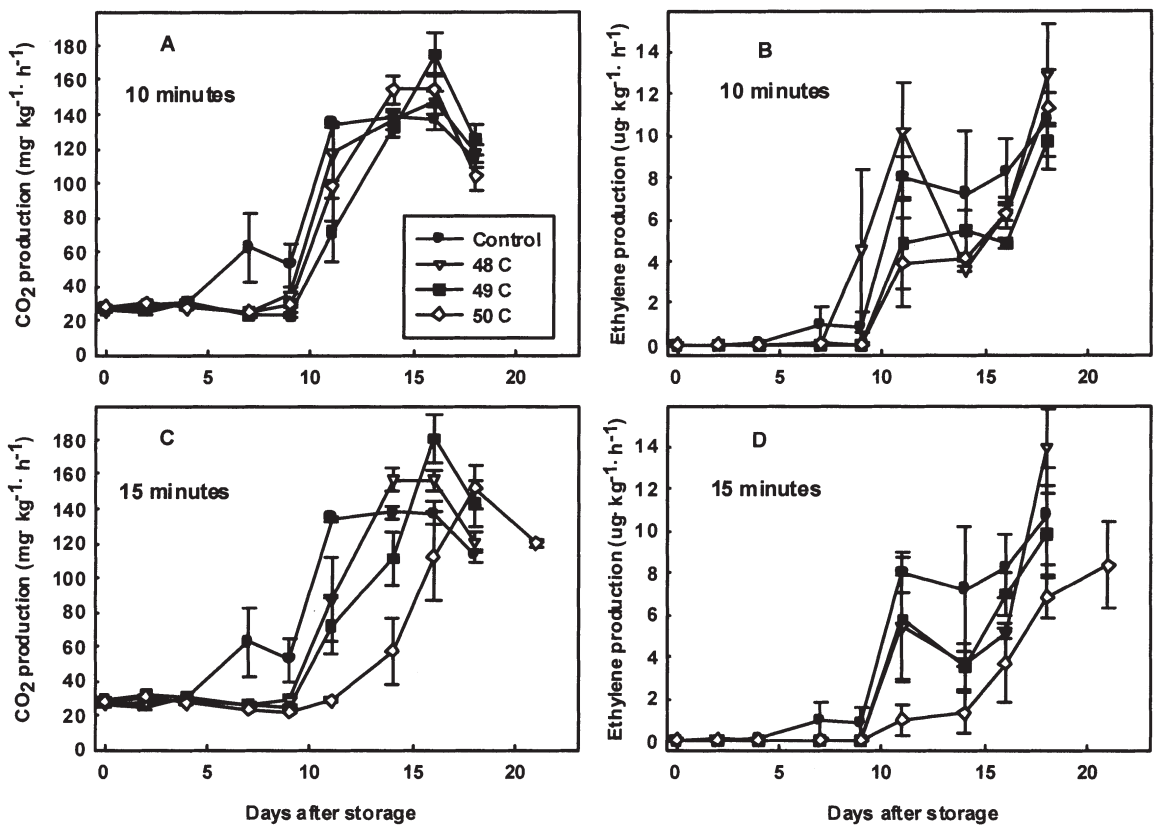

Fig. 2. Carbon dioxide (A and $\mathbf{C}$ ) and ethylene ( $\mathbf{B}$ and $\mathbf{D})$ production of winter-harvested 'Brazilian' bananas immersed in 48,49 , and $50^{\circ} \mathbf{C}$ hot water for 10 (A and $\mathbf{B}$ ) or 15 (C and $\left.\mathbf{D}\right) \mathrm{min}$.

(Fig. 2d). Heat treatments more severe than $49^{\circ} \mathrm{C}$ for 15 min may compromise the fruit's ability to rapidly recover the protein synthesis necessary for ethylene production.

Bananas lost weight during storage and ripening, and treatment effects were significant $(P=0.0001)$ (Table 4). However, only bananas immersed in $50{ }^{\circ} \mathrm{C}$ water for $15 \mathrm{~min}$ had greater weight loss (14.9\%) than nontreated fruit (11\%). Most of the weight loss occurred during ripening when the relative humidity $(\mathrm{RH})$ averaged $70 \%$. Therefore, the vapor pressure deficit was likely too high, and the evaporation rate was excessive during ripening (Turner, 1997). The percent weight loss averaged only $2 \%$ to $4 \%$ during the storage period when the RH was maintained at $89 \%$ (data not shown).
Hot water immersion treatments affected the banana peel firmness $(P=0.004)$ more so than pulp firmness $(P=0.05)$. The 49 and $50{ }^{\circ} \mathrm{C}$ treatments for 10 or 15 min durations tended to have firmer peels than the control fruit (Table 4). Control fruit had similar pulp firmness as bananas exposed to any of the hot water treatments. 'Dwarf Brazilian' bananas failed to soften after exposure to $55{ }^{\circ} \mathrm{C}$ hot water for $10 \mathrm{~min}$ or longer (Reyes et al., 1998). In other fruit, abnormal softening is a symptom of thermal injury during quarantine treatment for fruit fly control (Diaz-Perez et al., 2001; Paull and Chen, 1990).

Visual ratings for peel injury were different among treatments $(P=0.001)$, but only fruit exposed to 49 or $50{ }^{\circ} \mathrm{C}$ for $15 \mathrm{~min}$ had more visible discoloration than control fruit (Table
4). The discoloration appeared mostly on the shoulders and ridges of individual fingers and was similar to mild chilling injury symptoms (dull brown or gray, under-peel discoloration). High vapor pressure deficits during ripening can produce peel symptoms similar to chilling injury (Turner, 1997), and this may explain the peel discoloration of the control fruit and some hot water treated fruit. In all cases the visible peel discoloration was mild, such that surface color measurements of ripened fruit were not affected by hot water immersion $(P=0.11$ for lightness and $P=0.74$ for hue angle) (Table 4 ).

Armstrong (1982) reported that banana appearance was not impacted by a $15 \mathrm{~min}$ exposure to $50{ }^{\circ} \mathrm{C}$ hot water. In another report, scald generally occured only on bananas immersed in $50{ }^{\circ} \mathrm{C}$ water for $30 \mathrm{~min}$ or longer, but mild scald was observed on some fruit after a 20 min exposure (Reyes et al., 1998). Bananas exposed to $50{ }^{\circ} \mathrm{C}$ hot air for 15 or 30 min had scald on about $10 \%$ and $30 \%$ of the peel surface area, respectively (Jiang et al., 2002). Higher temperatures $\left(55^{\circ} \mathrm{C}\right)$ caused fruit damage even at short exposure times (Armstrong, 1982; Reyes et al., 1998).

\section{Conclusions}

Hot water immersion treatments below $50{ }^{\circ} \mathrm{C}$ for $<15$ min generally did not reduce the quality of 'Brazilian' bananas. Immersion at 48 to $49{ }^{\circ} \mathrm{C}$ for $15 \mathrm{~min}$ may be an effective quarantine treatment for surface insects, because a $48.2{ }^{\circ} \mathrm{C}$ treatment for 12.5 min killed coconut scales on the surface of bananas (unpublished data). In both experiments, bananas exposed to $49{ }^{\circ} \mathrm{C}$ water for $15 \mathrm{~min}$ ripened 2 to $3 \mathrm{~d}$ later than control fruit. Delayed ripening can be an advantage during postharvest handling, especially when fruit are shipped long distance from Hawaii. Exact temperature control would be necessary if a $49{ }^{\circ} \mathrm{C}$ treatment for $15 \mathrm{~min}$ is used for quarantine purposes, because a $1{ }^{\circ} \mathrm{C}$ temperature increase could injure the fruit.

Table 4. Percent weight loss, firmness, and peel characteristics of winter-harvested 'Brazilian' bananas following hot water immersion treatments, storage at 14 ${ }^{\circ} \mathrm{C}$ for $12 \mathrm{~d}$, and ripening at $22^{\circ} \mathrm{C}$.

\begin{tabular}{|c|c|c|c|c|c|c|c|}
\hline \multirow[b]{2}{*}{ Treatment } & \multirow{2}{*}{$\begin{array}{l}\text { Stage of } \\
\text { maturity }\end{array}$} & \multirow{2}{*}{$\begin{array}{c}\text { Wt } \\
\text { loss }(\%)^{y}\end{array}$} & \multicolumn{2}{|c|}{ Firmness $(\mathrm{N})^{\mathrm{x}}$} & \multicolumn{2}{|c|}{ Peel color ${ }^{w}$} & \multirow{2}{*}{$\begin{array}{c}\text { Peel } \\
\text { injury } \\
\text { rating }^{v}\end{array}$} \\
\hline & & & Peel & Pulp & $\mathrm{L}^{*}$ & Hue $\left(^{\circ}\right)$ & \\
\hline Control & $6.5 \mathrm{abc}^{\mathrm{u}}$ & $11.1 \mathrm{a}$ & $14.32 \mathrm{a}$ & $4.61 \mathrm{ab}$ & $71.8 \mathrm{a}$ & $89.9 \mathrm{a}$ & $1.4 \mathrm{bc}$ \\
\hline $48^{\circ} \mathrm{C}, 5 \mathrm{~min}$ & $6.5 \mathrm{abc}$ & $12.7 \mathrm{ab}$ & $14.39 \mathrm{a}$ & $4.76 \mathrm{ab}$ & $72.1 \mathrm{a}$ & $88.8 \mathrm{a}$ & $1.0 \mathrm{a}$ \\
\hline $10 \mathrm{~min}$ & $6.7 \mathrm{c}$ & $12.3 \mathrm{a}$ & $16.91 \mathrm{abc}$ & $4.98 \mathrm{~b}$ & $70.3 \mathrm{a}$ & $88.3 \mathrm{a}$ & $1.1 \mathrm{ab}$ \\
\hline $15 \mathrm{~min}$ & $6.6 \mathrm{bc}$ & $12.4 \mathrm{ab}$ & $17.49 \mathrm{abc}$ & $4.57 \mathrm{ab}$ & $70.6 \mathrm{a}$ & $88.1 \mathrm{a}$ & $1.6 \mathrm{c}$ \\
\hline $49^{\circ} \mathrm{C}, 5 \mathrm{~min}$ & $6.5 \mathrm{abc}$ & $12.0 \mathrm{a}$ & $15.98 \mathrm{ab}$ & $4.49 \mathrm{a}$ & $70.6 \mathrm{a}$ & $88.3 \mathrm{a}$ & $1.4 \mathrm{bc}$ \\
\hline $10 \mathrm{~min}$ & $6.5 \mathrm{abc}$ & $12.1 \mathrm{a}$ & $20.73 c$ & $4.83 \mathrm{ab}$ & $71.5 \mathrm{a}$ & $88.3 \mathrm{a}$ & $1.6 \mathrm{c}$ \\
\hline $15 \mathrm{~min}$ & $6.4 \mathrm{ab}$ & $12.6 \mathrm{ab}$ & $19.51 \mathrm{bc}$ & $4.76 \mathrm{ab}$ & $70.4 \mathrm{a}$ & $88.1 \mathrm{a}$ & $2.1 \mathrm{~d}$ \\
\hline $50^{\circ} \mathrm{C}, 5 \mathrm{~min}$ & $6.3 \mathrm{a}$ & $11.5 \mathrm{a}$ & $17.25 \mathrm{abc}$ & $4.72 a b$ & $71.0 \mathrm{a}$ & $88.6 \mathrm{a}$ & $1.4 \mathrm{bc}$ \\
\hline $10 \mathrm{~min}$ & $6.2 \mathrm{a}$ & $11.4 \mathrm{a}$ & $19.01 \mathrm{bc}$ & $4.74 \mathrm{ab}$ & $70.6 \mathrm{a}$ & $88.0 \mathrm{a}$ & $1.5 \mathrm{c}$ \\
\hline $15 \mathrm{~min}$ & $6.3 \mathrm{a}$ & $14.9 \mathrm{~b}$ & $18.04 \mathrm{abc}$ & $4.45 \mathrm{a}$ & $69.6 \mathrm{a}$ & $87.8 \mathrm{a}$ & $2.1 \mathrm{~d}$ \\
\hline
\end{tabular}

${ }^{2}$ Mean stage of ripeness when destructive analyses were performed. Stage of ripenesss was assessed on peel color using a scale of $1=$ dark green, $2=$ green with a trace of yellow, 3 = more green than yellow, $4=$ more yellow than green, $5=$ green tip, $6=$ fully yellow, and $7=$ yellow with black spots. Values are means of 16 observations.

'Weight loss values are means of four replications, with a composite sample of three bananas per replication.

${ }^{x}$ Firmness values are means of 12 observations.

${ }^{\mathrm{w}}$ Lightness $\left(\mathrm{L}^{*}\right)$ is on a scale of 0 to 100 . A hue angle of $90^{\circ}=$ yellow. Values are means of 16 observations.

'Percentage of the surface area showing discoloration, where a rating of $0=0 \%, 1=1 \%$ to $20 \%, 2=21 \%$ to $40 \%, 3=41 \%$ to $60 \%, 4=61 \%$ to $80 \%$, and $5=$ $81 \%$ to $100 \%$. Values are means of 16 observations.

uMeans within columns followed by the same letter are not significantly different $(P>0.05)$. 
More research is needed to determine whether a 10 min exposure to $49^{\circ} \mathrm{C}$ water would kill surface insects. This treatment also would insure good fruit quality.

\section{Literature Cited}

Armstrong, J.W. 1982. Development of a hot-water immersion quarantine treatment for Hawaiiangrown 'Brazilian' bananas. J. Econ. Entomol. 75:787-790.

Armstrong, J.W. 1983. Infestation biology of three fruit fly (Diptera:Tephritidae) species on 'Brazilian', 'Valery', and 'Williams' cultivars of banana in Hawaii. J. Econ. Entomol. 76:539-543.

Armstrong, J.W. 2001. Quarantine security of bananas at harvest maturity against Mediterranean and oriental fruit flies (Diptera:Tephritidae) in Hawaii. J. Econ. Entomol. 94:302-314.

Beaudry, R.M., R.F. Severson, C.C. Black, and S.J. Kays. 1989. Banana ripening: implications of changes in glycolytic intermediate concentrations, glycolytic and gluconeogenic carbon flux, and fructose 2,6-bisphosphate concentration. Plant Physiol. 91:1436-1444.

Blakeney, A.B. and L.L. Mutton. 1980. Simple colorimetric method for the determination of sugars in fruit and vegetables. J. Sci. Food Agr. 31:889-897.

Chan, H.T. 1986. Effect of heat treatment on the ethylene forming enzyme system in papayas. $\mathrm{J}$. Food Sci. 51:581-583.

Couey, H.M. 1989. Heat treatment for control of postharvest diseases and insect pests of fruits. HortScience 24:198-202.

Couey, H.M. and C.F. Hayes. 1986. Quarantine pro- cedure for Hawaiian papaya using fruit selection and a two-stage hot-water immersion. J. Econ. Entomol. 77:984-988.

Del Monte Fresh Produce. 1992. The banana ripening manual. Del Monte Fresh Produce Co., Coral Gables, Fla.

Diaz-Perez, J.C., A. Mejia, S. Bautista, R. Zavaleta, R. Villanueva, and R. Lopez Gomez. 2001. Response of sapote mamey [Pouteria sapota (Jacq.) H.E. Moore \& Stearn] fruit to hot water treatments. Postharvest Biol. Technol. 22:159-167.

Follett, P.A. and S.S. Sanxter. 2002. Longan quality after hot-water immersion and $\mathrm{x}$-ray irradiation quarantine treatments. HortScience 37:571-574.

Follett, P.A. and S.S. Sanxter. 2003. Lychee quality after hot-water immersion and $\mathrm{x}$-ray irradiation quarantine treatments. HortScience 38:1159-1162.

Gould, W.P. and J.L. Sharp. 1992. Hot water immersion quarantine treatment for guava infested with Caribbean fruit fly (Diptera: Tephritidae). J. Econ. Entomol. 85:1235-1239.

Hagenimana, V., R.E. Simard, and L. Vezina. 1994. Amylolytic activity in germinating sweetpotato (Ipomoea batatas L.) roots. J. Amer. Soc. Hort. Sci. 119:313-320.

Hawaii Agricultural Statistics Service. 2002. Hawaii bananas annual summary. Hawaii Dept. Agr. and USDA, Honolulu. (http://www.nass.usda. gov/hi/fruit/annban.htm).

Jiang, Y., D.C. Joyce, and A.J. Macnish. 2002. Softening response of banana fruit treated with 1-methycyclopropene to high temperature exposure. Plant Growth Regulat. 36:7-11.
Ketsa, S., S. Chidtragool, J.D. Klein, and S. Lurie. 1999. Ethylene synthesis in mango fruit following heat treatment. Postharvest Biol. Technol. 15:65-72.

Li, B.W., K.W. Andrews, and P.R. Pehrsson. 2002. Individual sugars, soluble and insoluble dietary fiber contents of 70 high consumption foods. J. Food Comp. Anal. 15:715-723.

Paull, R.E. and N.J.Chen. 1990. Heat shock response in field grown ripening papaya fruit. J. Amer. Soc. Hort. Sci. 115:623-631.

Paull, R.E. 1996. Ethylene, storage and ripening temperatures affect Dwarf Brazilian banana finger drop. Postharvest Biol. Tech. 8:65-74.

Paull, R.E. and N.J. Chen. 2000. Heat treatment and fruit ripening. Postharvest Biol. Tech. 21:21-37.

Reyes, M.E., W. Nishijima, and R.E. Paull. 1998. Control of crown rot in 'Santa Catarina Prata' and 'Williams' banana with hot water treatments. Postharvest Biol. Technol. 14:71-75.

SAS Institute. 1999. SAS system for Windows, version 8. SAS Inst., Cary, N.C.

Seymour, G.B. 1993. Banana, p. 83-106. In: G. Seymour, J. Taylor, and G. Tucker (eds.). Biochemistry of fruit ripening. Chapman and Hall, London.

Sharp, J.L. and D.H. Spalding. 1984. Hot water as a quarantine treatment for Florida mangoes infested with Caribbean fruit fly. Proc. Fla. State Hort. Soc. 97:355-357.

Simmonds, N.W. 1954. Notes on banana varieties in Hawaii. Pacific Sci. 8:226-229.

Turner, D.W. 1997. Bananas and plantains, p. 47-83. In: S.K. Mitra (ed.). Postharvest physiology and storage of tropical and subtropical fruits. $\mathrm{CAB}$ Intl., New York. 